\title{
Two new Bacidina species (Lecanorales, Ascomycota) from Pakistan
}

\author{
Maham Fatima $^{1 *}$, Kamran Habib ${ }^{1}$, Pawel Czarnota ${ }^{2}$, Abdul Nasir Khalid ${ }^{1}$ \\ ${ }^{1}$ Department of Botany, University of the Punjab, 54590 Lahore, Pakistan \\ *E-mail: mahamf40@gmail.com \\ ${ }^{2}$ Department of Ecology and Environmental Protection, Institute of Agricultural Sciences, Land Management \\ and Environmental Protection, University of Rzeszów, Zelwerowicza 4, 35-601 Rzeszów, Poland
}

\begin{abstract}
Bacidina margallensis and B. iqbalii from Pakistan are described and illustrated. Phylogeny of ITS nrDNA region confirms their position within the genus Bacidina, and morphological data make them distinct from other known species of the genus. Based on molecular data, corticolous Bacidina margallensis appears to be a sister species to B. chloroticula, but morphologically, when dry, is the most similar to known from Europe $B$. mendax because of the granular and warted greenish grey thallus, whitish-cream to dark brown and often piebald apothecia. It differs from that species by shorter, wider and less septate ascospores; 1-3-septate in B. margallensis vs 3-5(6)-septate in B. mendax, and by unusual parrot-green colour of wet thallus. Saxicolous Bacidina iqbalii is closely related to B. neosquamulosa but differs in having crustaceous thallus, transculent when wet entirely pale apothecia, larger asci and less septate large ascospores.
\end{abstract}

Keywords: lichenized fungi, Ramalinaceae, lichen taxonomy, molecular phylogeny, ITS nrDNA, Asia

\section{INTRODUCTION}

The genus Bacidina (Ramalinaceae, Lecanorales) was formally described by A. Vězda to accommodate 11 species, formerly classified as belonging to the genera Bacidia s.lat. and Catillaria s.lat., including Bacidia phacodes (Körb.) as the type species of the new genus (Vězda, 1990). Several years earlier, Vězda (1983) provided more precise characteristic features for the group of species establishing the new genus Bacidina. Although one of the basic generic features was the palecoloured apothecia without internal pigmentation, Bacidia egenula (Nyl.) Arnold, a species with dark apothecia and Arnoldiana-brown pigmented hypothecium was also included in the group by Vězda (1983). New discoveries and subsequent taxonomic studies by Ekman (1996, 2001), Coppins \& van den Boom (2002), Brand et al. (2009), Ekman et al. (2012), Czarnota \& Guzow-Krzemińska (2012, 2018), Kistenich et al. (2019), some of them based on molecular data, confirmed that also other darker-pigmented species belonged to this genus. Also, the goniocystoid thallus, as it was originally described in the protologue, appeared to be morphologically difficult to clearly define. The thallus structure of currently known Bacidina species ranges from indistinct, granular, crustaceous, warted, areolate, microsquamulous to distinctly sorediate (e.g. Vězda, 1983; Ekman, 1996; Aptroot \& van Herk, 1999; Czarnota \& Guzow-Krzemińska, 2012; Lumbsch et al., 2011; Kondratyuk et al.,
2019). Acicular ascospores, Lecanora-type asci, absence of secondary substances and more or less paraplectenchymatous excipulum at least in its outermost part, as well as the long, filiform conidia (not discovered however in several species) remained features that until recently consistently characterized the genus. Bacidina brittoniana (Riddle) LaGreca \& S. Ekman (=B. varia S. Ekman; Ekman, 1996) and B. medialis (Tuck. ex Nyl.) Kistenich, Timdal, Bendiksby \& S. Ekman (=Bacidia medialis (Tuck. ex Nyl.) de Lesd.; Ekman, 1996), molecularly confirmed as phylogenetically related to the type species of the genus Bacidina (Ekman, 2001; Kistenich et al., 2018), changed that imagination since both species are characterized by \pm bacilliform ascospores. Additionally, B. lacerata (Timdal) Kistenich, Timdal, Bendiksby \& S. Ekman (三Phyllopsora lacerata Timdal; Kistenich et al., 2018), known from Neotropics, forms distinctly squamulous thallus (Timdal, 2008). There is no doubt, that the genus Bacidina forms two separate phylogenetic groups. The core group of the genus Woessia with type species, W. fusarioides D. Hawskw., Poelt \& Tscherm-Woess. (=Bacidina sulphurella (Samp.) M. Hauck \& V. Wirth), is molecularly well-supported and much better defined (Ekman, 2001; Kistenich et al., 2018). Since the monophyly of the genus is still an unresolved problem reflecting in the species nomenclature, two further species recently dis- 
covered in Pakistan and taxonomically (including ITS nrDNA data) related to this core group have been described here under the names $B$. margallensis M. Fatima, K. Habib \& A. N. Khalid and B. iqbalii K. Habib \& A. N. Khalid. Thus, the number of Bacidina representatives known to date in Asia has increased to thirteen species according to our estimation (https://www.gbif. org/occurrence $/$ search?offset $=20 \& q=$ Bacidina \&continent=ASIA), while in the world it has exceeded 50 taxa (Czarnota \& Guzow-Krzemińska, 2018; MycoBank, 2020).

\section{MATERIAL AND METHODS}

\section{Collection and preservation}

Specimens were collected during surveys of different sites of Pakistan in years 2018 \& 2019, focused on an addition to the lichen biota of Pakistan. The specimens are deposited in Department of Botany, University of the Punjab, Lahore (LAH).

\section{Morphological and chemical characteriza- tion}

Specimens were examined macro- and micromorphologically with a stereomicroscope (Meiji Techno, EMZ-5TR, Japan) and a compound microscope (SWIFT M4000-D) along with System (9MP camera), respectively. The chemistry was analysed using spot tests. Anatomical characterization and measurement of anatomical features was done by preparing and observing the slides of hand-cut apothecial sections (mounted in water, $\mathrm{KOH}$ and Lugol's-IKI solution) under microscope. Minimum twenty measurements in water were made for each diagnostic feature.

\section{DNA extraction, PCR amplification and se- quencing}

For molecular studies, DNA isolation was performed, followed by amplification of targeted internal transcribed spacer region (ITS nrDNA), sequencing and phylogeny for accurate identification up to the species level.

Genomic DNA was extracted directly from a portion of thallus with apothecia from each specimen using a modified 2\% CTAB method (Gardes \& Bruns, 1993). The ITS-nrDNA region (Internal Transcribed Spacer of the nrDNA) was amplified using the primers pair ITS1F (forward primer) (Gardes \& Bruns, 1993) and ITS4 (reverse primer) (White et al., 1990), following the amplification protocol of Khan et al. (2018).

The amplified DNA fragments (PCR products) were visualized with the help of $1 \%$ agarose gel using ethidium bromide through Gel documentation system (Sambrook \& Russel, 2001). PCR products were sent for sequencing to Tsingke, China.

\section{Phylogenetic analysis}

Bidirectional sequences (ITS1 and ITS4) were reassembled by using BioEdit software (Hall, 1999). ITS sequences were retrieved using Basic Local Alignment Search Tool (BLAST) analysis. Maximum percent identification and query coverage of sequences with related taxa was found out. Multiple sequences (including sequences retrieved from GenBank) were aligned using webPRANK multiple alignment software with default parameters (Löytynoja \& Goldman, 2010). All sequences were trimmed at their ends to nearly equal number of sites using BioEdit. The phylogenetic tree was executed by software MEGA 7.0 (Kumar et al., 2016). The evolutionary history was retrieved with Maximum Likelihood Method based on Kimura 2-parameter. The model was selected by searching best DNA model for ML analysis in MEGA 7.0 (Kumar et al., 2016). 1000 rapid bootstrap replicates were run to infer the evolutionary history of the species. An outgroup, i.e. Biatora hemipolia (Nyl.) S. Ekman \& Printzen, was selected for rooting the tree (Czarnota \& Guzow-Krzemińska, 2018).

Trees of similar topology were created using ML and MP analysis, and the ML tree was selected to present the results (Fig. 1).

\section{RESULTS AND DISCUSSION}

Two new ITS nrDNA sequences nested within phylogenetic branch of the genus Bacidina have been obtained; both representing the species unknown yet, described here as $B$. margallensis sp. nov. and $B$. iqbalii sp. nov. (for details see under Taxonomy). Altogether, 44 ITS rDNA sequences were analysed, including 42 obtained from the GenBank; of 562 characters, 357 were constant, 164 were variable and 110 were parsimony-informative. Molecular data for $B$. phacodes, the type species of the genus, have 
Fig. 1. The Maximum Likelihood tree of newly described Bacidina margallensis, B. iqbalii and related taxa (based on ITS sequences). Numbers above branch node represent ML bootstrap and below MP bootstrap $(\geq 50)$ based on 1000 replicates. Sequences generated from Pakistan collections are marked with $\bullet$
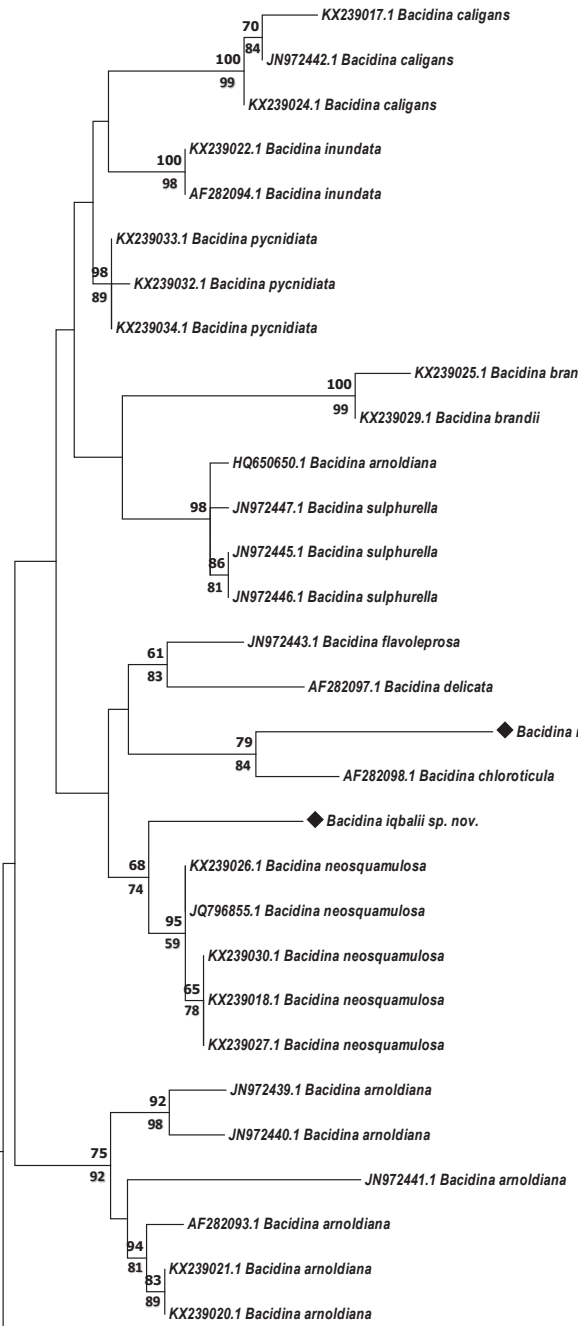

AF282095.1 Bacidina egenula

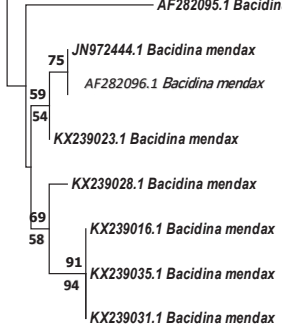

JQ796854.1 Bacidina delicat

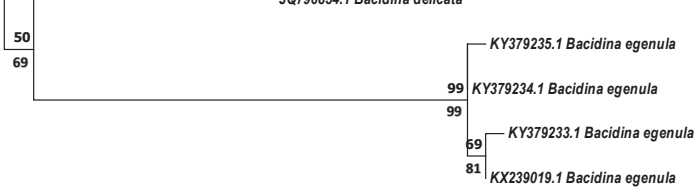


not been included here, since the species seems to not closely refer to the ITS rDNA branch of the rest, well known Bacidina species (Ekman, 2001; Czarnota \& Guzow-Krzemińska, 2012), except those recently included to the genus by Kistenich et al., (2018).

Bacidina margellensis appeared to be a sister species to B. chloroticula (Nyl.) Vězda \& Poelt (with 29 nucleotides differences between them). The branch representing them shows the bootstrap values of $79 \%$ in ML and $84 \%$ in MP analyses. The ITS lineage grouping both species is most related to the lineage of $B$. flavoleprosa Czarnota \& Guz.-Krzem. (Czarnota \& GuzowKrzemińska, 2012) and B. delicata (GenBank no. AF282097), but with no support. Similarly, its affinity to the sister branch including $B$. iqballi, the second newly discovered species, was also not supported sufficiently. Considering the two unrelated sequences of $B$. delicata obtained from GenBank, it is necessary to critically reexamine these sequenced specimens to establish the correct phylogenetic relationships between Bacidina species. Bacidina iqbalii is a sister species to B. neosquamulosa (Aptroot \& Herk) S. Ekman (up to 23 nucleotide differences based on ITS region's analysis). The branch representing them shows the bootstrap values of $68 \%$ in $\mathrm{ML}$ and $76 \%$ in MP analyses. Bacidina arnoldiana specimen (GenBank no. HQ650650), as previously proved by Czarnota \& Guzow-Krzemińska (2012), is nested in the well-supported lineage of $B$. sulphurella and should be renamed correctly in the GenBank dataset. Czarnota \& GuzowKrzemińska (2018) sequenced four specimens of $B$. egenula which are not related to the sequence of B. egenula (GenBank no. AF282095). For the placement of this specimen (GenBank no. AF282095), see comment by Czarnota \& GuzowKrzemińska (2018).

\section{TAXONOMY}

\section{Bacidina margallensis M. Fatima, K. Habib \& A. N. Khalid sp. nov. (Fig. $2 \mathrm{~A}-\mathrm{G}$ )}

\section{MycoBank no. MB 836878}

Characterized by granular to warted, olive to grey green thallus, large, whitish-cream to dark brown and often piebald apothecia, comparatively shorter 1-3-septate and wider ascospores than in similar species, $B$. mendax.
Type: Pakistan: Punjab, Islamabad, Margalla Hills $\left(33.74^{\circ} \mathrm{N}, 73.02^{\circ} \mathrm{E}\right), 1,604 \mathrm{~m}$ alt., on bark of Ficus infectoria Roxb. within sub-tropical scrub forest, 1 May 2019, A. N. Khalid \& K. Habib (MH-04) (LAH36417-holotype), ITS GenBank accession number: MT952886.

Description: Thallus crustaceous, irregular, variously structured, \pm thin, granular, \pm warted, tartareous, scattered (in the form of patches), non-goinocystoid, olive to grey green when dry or parrot green when wet; prothallus absent. Isidia and Soredia not found. Photobiont chlorococcoid, globose, 7-15 $\mu \mathrm{m}$ diam.

Apothecia single or clustered, at first \pm globose and widely marginate, later convex or becoming flat, sessile and constricted below hypothecium, rarely adnate, $0.2-0.5 \mathrm{~mm}$ in diam.; disk: whitish-cream, beige, brownish to dark brown, often piebald (pale orange to peach coloured and translucent when wet), epruinose; margins: slightly raised, persistent, broad and paler than disc when ascocarps young, later usually disappearing and at least partially concoloured with the disk or seldomly darker than the disk at maturity, pale to dark brown in upper part and paler on lateral surface; exciple: colourless throughout or pinkish brown in outer uppermost part when pigmented apothecia, K-, C-, laterally 20-40 $\mu \mathrm{m}$ wide, prosoplectenchymatous, having branched and tightly intertwined hyphae with 1.5-2 $\mu \mathrm{m}$ wide walls; hypothecium: entirely colourless, hyaline or slightly brownish in upper part, 20-50 $\mu \mathrm{m}$ wide; hymenium: colourless or partially slightly brownish, 40-55 $\mu \mathrm{m}$ tall; epihymenium: colourless or brownish in pigmented apothecia, pigment $\mathrm{K}-$, $\mathrm{C}$ - confined to gel matrix; asci: clavate, unitunicate, 8 -spored, 28-43 × 7-16 $\mu \mathrm{m}$; paraphyses: septate, simple or rarely sparsely branched, 2-3 $\mu$ m wide with apices swollen to $2.5-3.5 \mu \mathrm{m}$; ascospores: acicular, hyaline, straight or slightly curved, 15-20 $\times 1.5-2.5 \mu \mathrm{m}, 1-3$-septate. Pycnidia not found.

Chemistry: Thallus and apothecia; K-, C-, KC-.

Etymology: The epithet refers to type locality, Margalla Hills National Park.

Taxonomic remarks: The species is morphologically the most similar to recently described European taxon, Bacidina mendax Czarnota \& Guz.-Krzem., as both species exhibit nearly the same external and internal pigmentation of apothecia and, when dry, also the thallus 

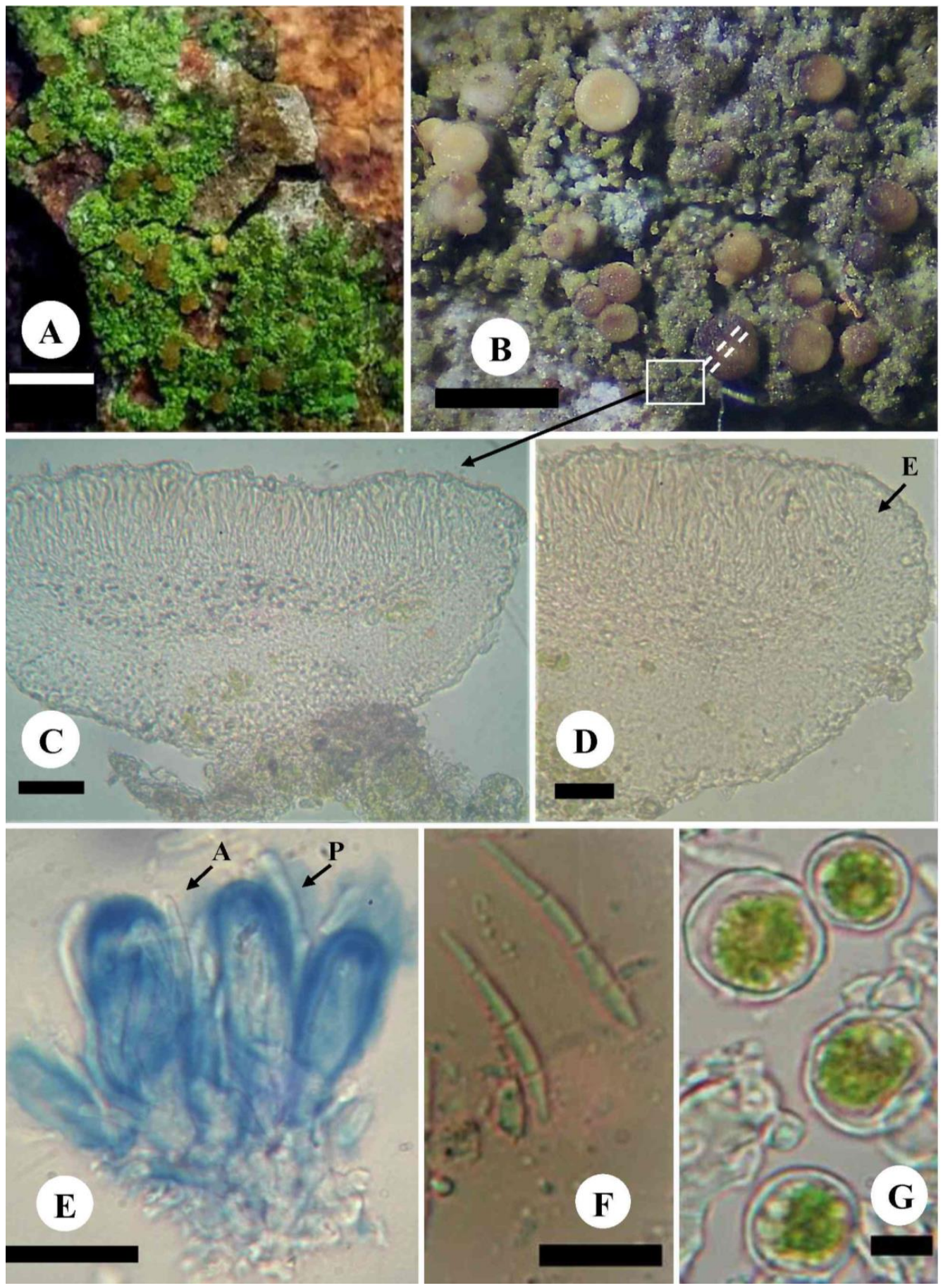

Fig. 2. Bacidina margallensis (LAH36417 - holotype; GenBank no. MT952886): A, habitus of wet specimen; B, habitus of dry specimen; C \& D, hand-cut apothecial section in water; E, asci and paraphyses; F, acicular ascospores, G, chlorococcoid photobiont. Scales: A = $1 \mathrm{~cm}$; B $=1 \mathrm{~mm}$; C $=30 \mu \mathrm{m} ; \mathrm{D}=40 \mu \mathrm{m} ; \mathrm{E}=15 \mu \mathrm{m}, \mathrm{F}=10 \mu \mathrm{m} ; \mathrm{G}=5 \mu \mathrm{m}$. 
colour and its structure. Distinct phenotypical differences are visible when both species are in wet conditions, because the thallus of $B$. margallensis turns parrot green, while the thallus of the second species remains almost unchanged. Differences between both species include also the size of ascospores, which are shorter and wider (15-20 × 1.5-2.5 $\mu \mathrm{m})$, and 1-3-septate in $B$. margallensis, while in $B$. mendax ascospores reach dimensions of $(25-) 30-38(-40) \times 1.2-1.5$ $\mu \mathrm{m}$ and appear 3-5(-6)-septate (Czarnota \& Guzow-Krzemińska, 2018). Both species are not closely related as showed their ITS rDNA phylogeny (Fig. 1). Diagnostic features distinguishing B. margallensis from other, phylogenetically related species of the genus are presented in Table 1.

Habitat and distribution: The taxon is known only from its locus typicus in the mountain Margalla Hills National Park, at the Himalayan foothills in Pakistan. It is corticolous (on bark of Ficus infectoria Roxb.), collected from subtropical scrub forest having mean max. $34.3^{\circ} \mathrm{C}$ and min. $3.4{ }^{\circ} \mathrm{C}$ temperature. Snow fall occurs occasionally in winter. The north facing slopes of Margalla Hills have a greater species diversity with the presence of Pinus roxburghii Sarg., Apluda mutica L., and Quercus incana Roxb. community as compared to south facing slopes having plant communities composed of Acacia modesta Wall., Woodfordia fruticosa Kurz., and Dodonaea viscosa Jacq.

\section{Bacidina iqbalii K. Habib \& A. N. Khalid sp. nov. (Fig. 3A-H)}

\section{MycoBank no. MB 836879}

Characterized by thick, cracked, crustaceous, olive green thallus, pale orange to beige-coloured apothecia translucent when wet, colourless, K-, $\mathrm{C}$ - hymenium and uppermost excipulum, and from the most similar $B$. jasonhuri differs in its longer and wider asci and ascospores and less septate ascospores.

Type: Pakistan: Khyber Pakhtunkhwa, Kaghan valley $\left(34.54^{\circ} \mathrm{N}, 73.35^{\circ} \mathrm{E}\right), 2,500 \mathrm{~m}$ alt., on granitic (crystalline) rock, 1 April 2019, A. N. Khalid and Kamran Habib (B-02) (LAH36418-holotype), ITS GenBank accession number: MT952885

Description: Thallus crustaceous, tartareous, composed of large patches of compacted rough areoles, olive to dark olivaceous green, dull, not dissolving into granular goniocysts; prothallus absent. Isidia and soredia not found. Photobiont chlorococcoid, broadly ellipsoid to globose, cells 7-14(-17) $\mu \mathrm{m}$ diam.

Apothecia $0.2-1.0 \mathrm{~mm}$ in diam., abundant, mostly single, seldomly clustered, at first \pm globose and moderately marginate, later becoming flat to convex, sessile, adnate; disk: peach to pale orange coloured (pinkish brown to pale brown and marginally translucent when wet), epruinose; margins: raised and uniformly paler than the disk when young, later becoming concoloured with the disk or disappear; exciple: hyaline inside, very pale brown outside, $\mathrm{K}-, \mathrm{C}-$, laterally $40-45 \mu \mathrm{m}$ wide, prosoplectenchymatous, composed of periclinally arranged, thin, tightly intertwined, radiating and branched hyphae, $1.0-2.5 \mu \mathrm{m}$ in diam.; hypothecium: colourless, hyaline, $20-40 \mu \mathrm{m}$ wide; hymenium: colourless or slightly brownish, K-, C-, 60-90 $\mu \mathrm{m}$ tall; epihymenium: colourless to pale brown; asci: Lecanora-type, cylindrical to clavate, unitunicate, with spirally coiled 8 spores, 49-74 $\times$ 7-19 $\mu \mathrm{m}$; paraphyses: septate, branched, 46-76 $\mu \mathrm{m}$, capitate having 3-6 $\mu \mathrm{m}$ wide apices; ascospores: acicular, hyaline, straight to slightly or moderately curved, 44-57 × 1.5-2.5 $\mu \mathrm{m}$, 1-4-septate. Pycnidia not found.

Chemistry: Thallus and apothecia; K-, C-, KC-.

Etymology: The epithet iqbalii refers to the name of the late famous Pakistani mycologist - Syed Hussain Iqbal.

Taxonomic remarks: Despite $B$. iqballi shows molecular affinity to $B$. neosquamulosa both species differ in their morphology and anatomy (Tab. 1). B. iqbalii has a compact, cracked thallus $v$ s. thallus of $B$. neosquamulosa composed of flattened and branched microsquamules, peach to orange apothecial disk vs. pinkish to fleshcoloured having blackened 'smoked' areas, taller hymenium (60-90 $\mu \mathrm{m} v \mathrm{~s} .45-60 \mu \mathrm{m})$, larger and wider asci $(49-74 \times 7-19 \mu \mathrm{m}$ vs. $45-60 \times 8-12$ $\mu \mathrm{m})$, wider ascospores (1.5-2.5 $\mu \mathrm{m}$ vs. $1.3-1.7$ $\mu \mathrm{m})$ and different number of spore septations (1-4 septa vs. 3-7 septa in B. neosquamulosa) (Aptroot \& Herk, 1999).

Recently described, another Asian saxicolous representative of the genus, Bacidina jasonhuri J. P. Halda, S. Y. Kondr. et L. Lökös, is morphologically similar to $B$. iqballi due to the persistently pale, concave apothecia and crustaceous 

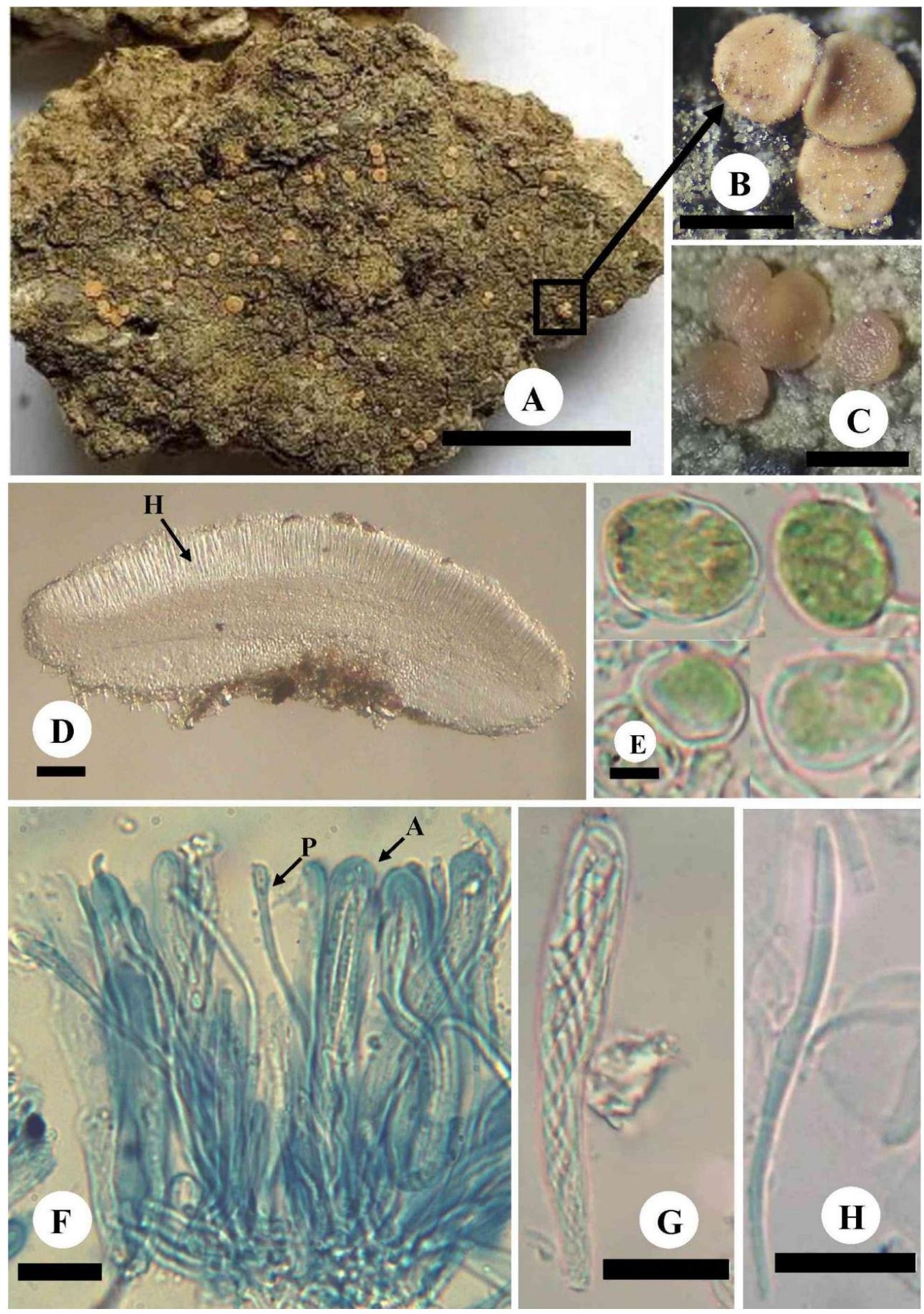

Fig. 3. Bacidina iqbalii (LAH36418 - holotype; GenBank no. MT952885 ): A, habitus; B, dry apothecia; C, wet apothecia; D, hand-made apothecial section in water; E, chlorococcoid photobiont $\mathrm{F}$, asci and capitate paraphyses; $\mathrm{G}$, asci with spirally coiled ascospores; $\mathrm{H}$, acicular ascospores. Scales: $\mathrm{A}=1 \mathrm{~cm} ; \mathrm{B}=1 \mathrm{~mm} ; \mathrm{C}=1 \mathrm{~mm} ; \mathrm{D}=70 \mu \mathrm{m} ; \mathrm{E}=5 \mu \mathrm{m}, \mathrm{F}=15 \mu \mathrm{m} ; \mathrm{G}=15 \mu \mathrm{m} ; \mathrm{H}=15 \mu \mathrm{m}$. 


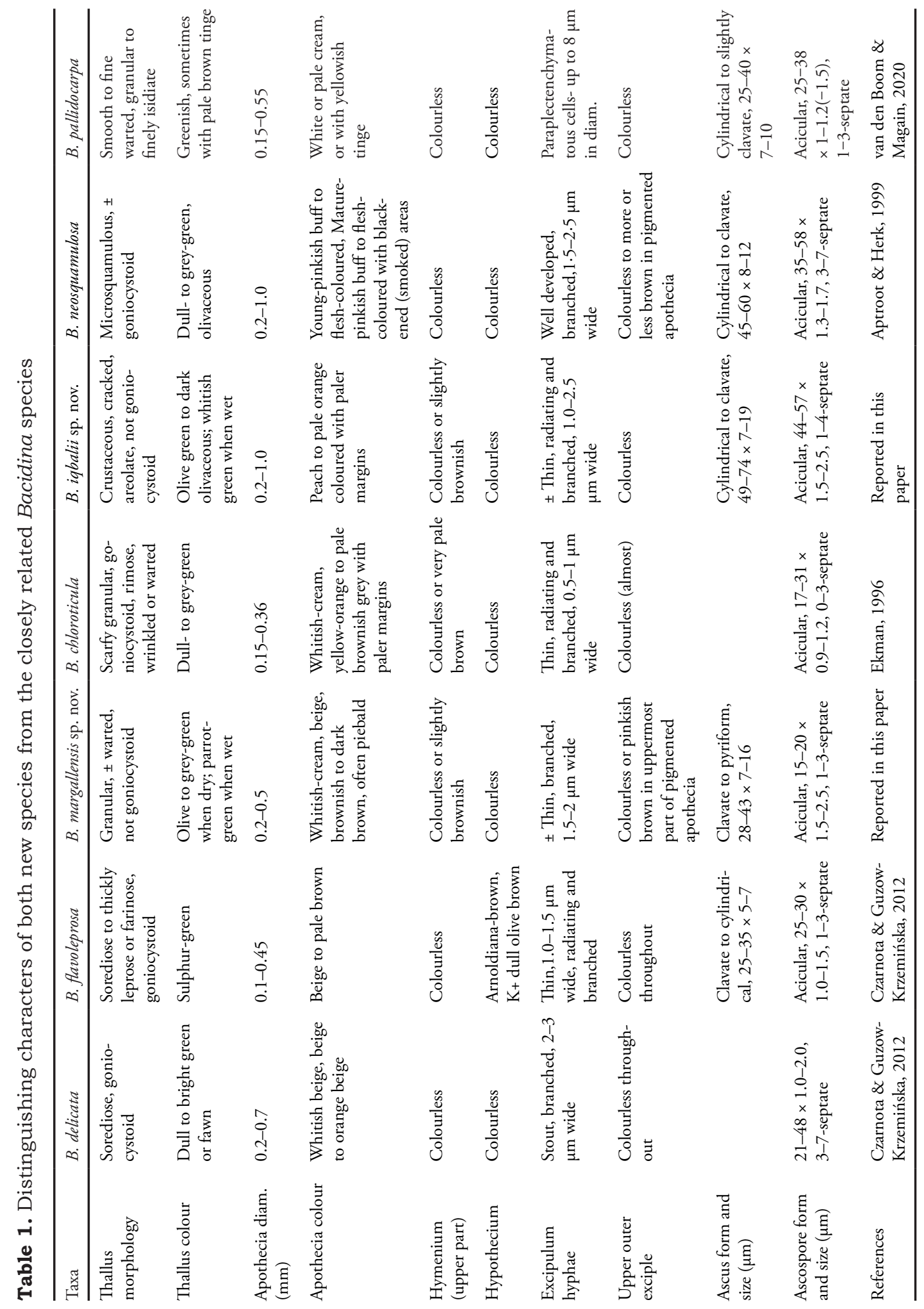


thallus (Kondratyuk et al., 2019). Photobiont cells and asci of $B$. jasonhuri are, however, distinctly smaller-sized, and its ascospores smaller and usually more septate; 44-57 × 1.5-2.5 $\mu \mathrm{m}$, 1-4-septate in B. iqballi vs 24-34 × 1.5-2.0 $\mu \mathrm{m}$, $3(-5)$-septate in B. jasonhuri. Moreover, campylidioid pycnidia as found in B. jasonhuri are unknown in most representatives of the genus, and conidiomata in $B$. iqballi have not been found in any form.

Because of pale, transculent, colourless inside apothecia and crustaceous thallus Bacidina iqbalii can resemble several other species including $B$. chloroticula and B. delicata (Larbal. ex Leight.) Coppins, which can inhibit rocky substrates (for comparison see Table 1, but note that molecular studies suggest that the later taxon should be more precisely defined). It also shares similar morphology with $B$. phacodes (Körb.) Vězda and $B$. neglecta (Vězda) Vězda, being sometimes synonymized with $B$. chloroticula (Ekman et al., 2012), but apart from anatomical differences, both species are not saxicolous.

Habitat and Distribution: B. iqballi is known only from the type locality in Pakistan to be growing on rain-exposed and shaded granitic (crystalline) rock in a deep, alpine (up to 5,000 m a.s.1.), partially forested Kaghan valley with a mean max. and min. temperature: $21.5^{\circ} \mathrm{C}$ and $1.8^{\circ} \mathrm{C}$, respectively. It is a biologically, geo-physically, and hydrologically dynamic area. Additionally, the valley displays beautiful wonderland in view of its transcending Himalayan peaks, peaceful lakes, majestic glaciers and water falls.

\section{ACKNOWLEDGEMENT}

We sincerely thank Prof. Dr. Andre Aptroot (Laboratório de Botânica/Liquenologia, UFMS Campo Grande, Brazil) for his initial comments on Bacidina iqbalii sp. nov.

\section{REFERENCES}

Aptroot, A., \& van Herk, C. M. 1999. Bacidia neosquamulosa, a new and rapidly spreading corticolous lichen species from Western Europe. The Lichenologist 31(2): 121-127. https://doi.org/10.1006/ lich. 1998.0184

Boom, P. van den \& Magain, N. 2020. Three new lichen species from Macaronesia belonging in Ramalinaceae, with the description of a new genus. Plant and Fungal Systematics, 65 (1): 167-175. https:/ / doi.org/10.35535/pfsyst-2020-0011

Brand, M., Coppins, B. J., van den Boom, P. P. G. \& Sérusiaux, E. 2009. Further data on the lichen genus Bacidia s. 1. in the Canary Islands and Western Europe, with descriptions of two new species. Bibliotheca Lichenologica 99: 81-92.

Coppins, B. J. \& van den Boom, P. P. G. 2002. Bacidia brandii, a new lichen species from the Netherlands, Belgium, France and Lithuania. The Lichenologist 34(4): 327-332. https://doi. org/10.1006/lich.2002.0403

Czarnota, P. \& Guzow-Krzemińska, B. 2012. ITS rDNA data confirm a delimitation of Bacidina arnoldiana and $B$. sulphurella and support a description of a new species within the genus Bacidina. The Lichenologist 44(6): 743-755. https://doi. org/ 10.1017/S0024282912000515

Czarnota, P. \& Guzow-Krzemińska, B. 2018. Bacidina mendax sp. nov., a new widespread species in Central Europe, together with a new combination within the genus Bacidina. The Lichenologist 50(1): 43-57. https://doi.org/10.1017/ S0024282917000627

Ekman, S. 1996. The corticolous and lignicolous species of Bacidia and Bacidina in North America. Opera Botanica 127: 1-148.

Ekman, S. 2001. Molecular phylogeny of the Bacidiaceae (Lecanorales, lichenized Ascomycota). Mycological Research 105(7): 783-797. https:// doi.org/10.1017/S0953756201004269

Ekman, S., Jonsson, F. \& Hermansson, J. 2012. Bacidina etayana and B. saxenii new to Sweden. Graphis Scripta 24: 14-18.

Gardes, M. \& Bruns, T. D. 1993. ITS primers with enhanced specificity for basidiomycetes-application to the identification of mycorrhizae and rusts. Molecular Ecology 2(2): 113-118. https://doi. org/10.1111/j.1365-294X.1993.tb00005.x

Hall, T. A. 1999. BioEdit: a user-friendly biological sequence alignment editor and analysis program for Windows 95/98/NT. Nucleic Acids Symposium Series 41: 95-98.

Khan, M., Khalid, A. N. \& Lumbsch,, T. (2018). A new species of Lecidea (Lecanorales, Ascomycota) from Pakistan. MycoKeys, 38, 25-34. https:// doi.org/ 10.3897/mycokeys.38.26960

Kistenich, S., Bendiksby, M., Ekman, S., Cáceres, M. E. S., Hernández, M. J. E. \& Timdal, E. (2019). Towards an integrative taxonomy of Phyllopsora (Ramalinaceae). The Lichenologist, 51(4): 323-392. https://doi.org/10.1017/S0024282919000252

Kistenich, S., Timdal, E., Bendiksby, M. \& Ekman, S. (2018). Molecular systematics and character evolution in the lichen family Ramalinaceae (Ascomycota: Lecanorales). Taxon 67: 871-904. https://doi.org/10.12705/675.1

Kondratyuk, S. Y., Lőkös, L., Farkas, E., Jang, S.-H., Liu, D., Halda, J., Persson, P.-E., Hansson, M., 
Kärnefelt, I., Thell, A., Fačkovcová, Z., Yamamoto, Y. \& Hur, J.-S. 2019. New and noteworthy lichen-forming and lichenicolous fungi 9. Acta Botanica Hungarica 61(3-4): 325-367. https:// doi.org/10.1556/034.61.2019.3-4.6

Kumar, S., Stecher, G. \& Tamura, K. 2016. MEGA7: Molecular evolutionary genetics analysis version 7.0 for bigger datasets. Molecular Biology and Evolution 33(7): 1870-1874. https://doi. org/10.1093/molbev/msw054

Löytynoja, A. \& Goldman, N. 2010. webPRANK: a phylogeny-aware multiple sequence aligner with interactive alignment browser. BMC Bioinformatics 11: 579. https://doi.org/10.1186/1471-210511-579

Lumbsch, H. T., Ahti, T., Altermann S., De Paz, G. A., Aptroot, A., Arup, U. \& Lücking, R. 2011. One hundred new species of lichenized fungi: a signature of undiscovered global diversity. Phytotaxa 18: 1-127. https://doi.org/10.11646/ phytotaxa.18.1.1

Sambrook, J. \& Russel, D.W. 2001. Rapid isolation of yeast DNA. In: Sambrook, J. \& Russel, D. W. (eds). Molecular cloning: A laboratory manual. Cold Spring Harbor Laboratory Press, New York. 631-632 pp.

Timdal, E. 2008. Studies on Phyllopsora (Ramalinaceae) in Peru. The Lichenologist 40(4): 337-362. https://doi.org/10.1017/S0024282908007846

Vězda, A. 1983. Foliicole Flechten aus der Kolchis (West-Transkaukasien, UdSSR). Folia Geobotanica et Phytotaxonomica 18: 45-70. https: / / doi. org/ 10.1007/BF02855637

Vězda, A. 1990. Bacidina genus novum familiae Lecideaceae s. lat. (Ascomycetes lichenisati). Folia Geobotanica et Phytotaxonomica 25: 431-432. https: / /doi.org/10.1007/BF02914011

White, T. J., Bruns, T., Lee, S. \& Taylor, J. W. (1990). Amplification and direct sequencing of fungal ribosomal RNA genes for phylogenetics. In: Innis, M. A., Gelfand, D. H., Sninsky, J. J. \& White, T. J. (eds). PCR protocols: a guide to methods and application. Academic press, New York. 315-322 pp. https: / / doi.org/10.1016/B978-0-12-3721808.50042-1 